OPEN ACCESS

Edited by:

Steve Bibevski,

Joe DiMaggio Children's Hospital,

United States

Reviewed by:

Gabriela Kania,

University Hospital Zürich, Switzerland

Elisa Avolio,

University of Bristol, United Kingdom

${ }^{*}$ Correspondence:

Dawn A. Delfín

ddelfin@salud.unm.edu

Specialty section:

This article was submitted to

Cardiovascular Biologics and

Regenerative Medicine,

a section of the journal

Frontiers in Cardiovascular Medicine

Received: 05 November 2018

Accepted: 20 February 2019

Published: 14 March 2019

Citation:

Delfín DA, DeAguero JL and McKown EN (2019) The Extracellular Matrix Protein $A B / 3 B P$ in

Cardiovascular Health and Disease.

Front. Cardiovasc. Med. 6:23.

doi: 10.3389/fcvm.2019.00023

\section{The Extracellular Matrix Protein ABI3BP in Cardiovascular Health and Disease}

\author{
Dawn A. Delfín *, Joshua L. DeAguero and Elizabeth N. McKown \\ Department of Pharmaceutical Sciences, College of Pharmacy, University of New Mexico, Albuquerque, NM, United States
}

$\mathrm{ABI} 3 \mathrm{BP}$ is a relatively newly identified protein whose general biological functions are not yet fully defined. It is implicated in promoting cellular senescence and cell-extracellular matrix interactions, both of which are of vital importance in the cardiovascular system. ABI3BP has been shown in multiple studies to be expressed in the heart and vasculature, and to have a role in normal cardiovascular function and disease. However, its precise role in the cardiovascular system is not known. Because ABI3BP is present in the cardiovascular system and is altered in cardiovascular disease states, further investigation into ABI3BP's biological and biochemical importance in cardiovascular health and disease is warranted.

Keywords: ABI3BP, extracellular matrix, heart, vasculature, cardiovascular

\section{ABI3BP: AN OVERVIEW}

$\mathrm{ABI} 3 \mathrm{BP}$ is an extracellular matrix protein whose function is not well-known. However, previous and ongoing studies have demonstrated that $\mathrm{ABI} 3 \mathrm{BP}$ is of emerging importance in both health and disease. The $A B I 3 B P$ gene is expressed in multiple organs, including the heart, kidney, lung, pancreas, and placenta, with low-level or variable expression in the spleen, liver, brain, bone, and skeletal muscle (1-4). ABI3BP is best known for is its role in multiple forms of cancer, acting as a tumor suppressor via promotion of cellular senescence $(2,3,5-18)$. Although it is expressed in the heart and vasculature, its role in the cardiovascular system is not yet defined. Still, there are a limited number of studies highlighting that its presence, upregulation, or downregulation plays a role in cardiovascular health and disease states. This minireview will present the research published to date on $\mathrm{ABI} 3 \mathrm{BP}$ in the cardiovascular system.

The first study on ABI3BP was published in 2001 (1), after Matsuda et al., performed a yeast two-hybrid screen for binding partners of the $\mathrm{SH} 3$ binding domain of Nesh-SH3, also known as Abelson (Abl) interacting protein family member $\underline{3}$ (ABI3). Originally, the group named the newly identified gene, Tarsh because it was the target of Nesh-SH3. Today, it is known as Abl-interacting protein family member $\underline{3}$ binding protein, or ABI3BP.

At present, ABI3BP's general biological functions are largely unknown. Although it was identified in a yeast two-hybrid screen as a binding partner of the isolated $\mathrm{SH} 3$ domain of $\mathrm{ABI} 3$, it has not been empirically demonstrated that $\mathrm{ABI} 3 \mathrm{BP}$ and the full $\mathrm{ABI} 3$ protein interact. However, both $\mathrm{ABI} 3 \mathrm{BP}$ and $\mathrm{ABI} 3$ are downregulated in cancers with supporting evidence that they are both important in promoting cellular senescence $(1,14,19-21)$. ABI3BP is also known as an extracellular/interstitial matrix protein and plays a role in cell-substrate adhesion $(4,22-26)$. 
As a promotor of cellular senescence and cell-extracellular matrix binding interactions, it is possible that $\mathrm{ABI} 3 \mathrm{BP}$ regulates these processes in the cardiovascular system. The adult heart has almost negligible cardiomyocyte turnover $(27,28)$, and the mature cardiomyocyte is considered a terminal cell. Additionally, cardiac fibroblasts are present in a nonactivated state in the healthy myocardium (29, 30). Thus, ABI3BP may help maintain the non-proliferative state of the normal myocardium. Further, cell-extracellular matrix interactions are key in the heart and vasculature to organize the organ structure; provide biological, biochemical, and biophysical signals between the intracellular and extracellular environments; and provide mechanical strength against blood flow (31-35). ABI3BP may be an important component of the cell-extracellular matrix interactome in the cardiovascular system. Moreover, pathological extracellular matrix remodeling is a key feature of many cardiovascular diseases $(35,36)$. This pathological remodeling may affect or be affected by ABI3BP.

\section{THE CARDIOVASCULAR ROLE OF ABI3BP}

Research published to date shows that ABI3BP is expressed in the vasculature and the heart, but almost no more than that is currently known. A thorough and systematic study on the localization of $\mathrm{ABI} 3 \mathrm{BP}$ in the cardiovascular system is lacking. We and others have shown that $\mathrm{ABI} 3 \mathrm{BP}$ is present in the myocardium, the aorta, and in cardiac progenitor cells. Specific localization of ABI3BP in cardiovascular tissues and within cells has not yet been determined, but it is a research goal of our laboratory. Specific localization of ABI3BP will help clarify its potential role in cardiovascular health and disease.

The cardiovascular localization and roles of $\mathrm{ABI} 3 \mathrm{BP}$ as published to date is detailed below, and summarized in Table $\mathbf{1}$.

\section{ABI3BP in the Myocardial Extracellular Matrix}

ABI3BP is expressed in the decellularized extracellular matrix of the human heart's right and left atria (24) and the left ventricle (37), as identified in separate proteomics studies. In both studies, the heart tissue was decellularized, and the isolated extracellular matrix was subjected to mass spectrometry to identify global protein and glycoprotein alterations. ABI3BP (listed as "target of Nesh-SH3") was one of 12 extracellular matrix or matricellular proteins identified in our study of the extracellular matrix of the left ventricle (37), and one of 75 glycoproteins identified in the Barallobre-Barreiro atrial extracellular matrix study (24). We further showed that $\mathrm{ABI} 3 \mathrm{BP}$ levels are reduced by approximately half from the left ventricular extracellular matrix in failing human hearts with dilated cardiomyopathy (37). These studies support that $\mathrm{ABI} 3 \mathrm{BP}$ is present specifically in the extracellular matrix of the heart, where it can potentially perform its putative role in promoting cell-extracellular matrix interactions.
TABLE 1 | The cardiovascular localization and/or role of ABI3BP.

\begin{tabular}{|c|c|c|}
\hline $\begin{array}{l}\text { ABI3BP cardiovascular } \\
\text { localization and/or role }\end{array}$ & $\begin{array}{l}\text { Changes in } \\
\text { cardiovascular disease }\end{array}$ & References \\
\hline $\begin{array}{l}\text { Myocardial extracellular matrix } \\
\text { (right and left atria, left } \\
\text { ventricle) }\end{array}$ & $\begin{array}{l}\text { Reduced from left ventricle } \\
\text { in failing hearts }\end{array}$ & $(24,37)$ \\
\hline $\begin{array}{l}\text { Aorta, vascular endothelial } \\
\text { cells, vascular smooth muscle } \\
\text { cells }\end{array}$ & $\begin{array}{l}\text { Upregulated in stressed } \\
\text { vascular endothelial and } \\
\text { smooth muscle cells }\end{array}$ & $(22,38,39)$ \\
\hline $\begin{array}{l}\text { Cardiac progenitor cells } \\
\text { (CPCs) }\end{array}$ & $\begin{array}{l}\text { Reduces CPC proliferation, } \\
\text { promotes CPC } \\
\text { transdifferentiation toward } \\
\text { cardiomyocytes, protects } \\
\text { against myocardial } \\
\text { infarction, acts through } \\
\text { integrin- } \beta 1 \text { binding and } \\
\text { signaling }\end{array}$ & $(40)$ \\
\hline $\begin{array}{l}\text { Link between cardiovascular } \\
\text { disease and psychological } \\
\text { stress }\end{array}$ & $\begin{array}{l}\text { Single nucleotide } \\
\text { polymorphism (SNP) } \\
\text { associated with high blood } \\
\text { pressure in response to } \\
\text { unfair discrimination }\end{array}$ & $(41)$ \\
\hline Early-onset preeclampsia & $\begin{array}{l}\text { Upregulated in early-onset } \\
\text { preeclampsia }\end{array}$ & (42) \\
\hline $\begin{array}{l}\text { Protection against cigarette } \\
\text { smoke-induced emphysema }\end{array}$ & $\begin{array}{l}\text { Downregulated in a strain of } \\
\text { mice resistant to cigarette } \\
\text { smoke-induced } \\
\text { emphysema }\end{array}$ & (43) \\
\hline
\end{tabular}

\section{ABI3BP in the Vasculature and Vascular Cells}

ABI3BP (listed as "target of Nesh-SH3") was identified in a proteomics study of the isolated extracellular matrix of the human aorta (22), out of 103 total proteins identified. This was the first report of $\mathrm{ABI} 3 \mathrm{BP}$ in the vasculature, and its function there is still unknown. Endothelial cells, which line blood vessels, are sensitive to cardiovascular stress. In a proteomic analysis of the vesicular "secretome" of human umbilical vein endothelial cells (HUVECs), Yin et al., demonstrated that ABI3BP protein was found in serum-starved (stressed), phorbol-12-myristate-13acetate (PMA)-stimulated HUVECs (38). Scherer et al., knocked down the transcription factor nuclear factor of activated T-cells 5 (NFAT5) in vascular smooth muscle cells obtained from human umbilical cords. NFAT5 is known to control vascular smooth muscle cell phenotypes. After NFAT5 was knocked down in umbilical vascular smooth muscle cells, the cells were subjected to stretching stress. ABI3BP mRNA levels were upregulated 2.7fold in NFAT5 knockdown cells compared to cells expressing NFAT5, indicating that NFAT5 normally suppresses $A B I 3 B P$ expression in umbilical vascular smooth muscle cells (39). These studies demonstrate that $\mathrm{ABI} 3 \mathrm{BP}$ is expressed in the vasculature, including under starvation or stretching stress, and may play a role in blood vessels.

\section{ABI3BP in Cardiac Progenitor Cells}

Following a study of $A B I 3 B P$ in pluripotent stem cells, Hodgkinson et al., studied the effects of $A B I 3 B P$ knockout and knockdown in a cardiac stem cell, or $\mathrm{c}-\mathrm{Kit}^{+}$cardiac progenitor 
cells. They isolated cardiac progenitor cells from ABI3BPknockout and wild-type mice. They found that $A B I 3 B P$ mRNA and protein levels increased during the transdifferentiation process toward cardiomyocytes in wild-type cardiac progenitor cells, along with increases in markers of cardiomyocyte transdifferentiation, including Gata4, Gata6, Mef2C, and TNNI3 mRNA and protein. In contrast, ABI3BP-knockout cardiac progenitor cells showed significantly reduced levels of cardiomyocyte transdifferentiation markers. Reinstating $A B I 3 B P$ expression in knockout cardiac progenitor cells using an expression plasmid led to expression of differentiation markers. Wild-type and $A B I 3 B P$-knockout mice were subjected to myocardial infarction via coronary artery restriction, or a sham operation. Myocardial infarction induced $\mathrm{c}-\mathrm{Kit}^{+}$cardiac progenitor cells in both wild-type and $A B I 3 B P$-knockout mice, but more so in knockout mice. There was a higher abundance of double positive c-Kit ${ }^{+}$and $\mathrm{Gata}^{+}{ }^{+}$cells in wild-type infarcted mice compared to wild-type shams, indicating early-stage cardiac progenitor cell-to-cardiomyocyte transdifferentiation activity. However, this transdifferentiation was impaired in knockout mice. Wild-type mice showed a reduction in cardiac fibrosis and improved cardiac function 1 month post-myocardial infarction compared to $A B I 3 B P$ knockout mice. Blocking integrin- $\beta_{1}$ binding using antibodies inhibited cardiac progenitor cell transdifferentiation, indicating that the activity of $\mathrm{ABI} 3 \mathrm{BP}$ is mediated through integrin- $\beta_{1}$. Knockout cardiac progenitor cells showed reduced levels of phospho-protein kinase $c$ and phospho-Akt, which are downstream signaling factors of integrin- $\beta_{1}$. Thus, while cardiac progenitor cells were induced to a higher level in the ABI3BP knockout mice, they were blocked from commitment to the cardiomyocyte lineage (40). This implies that ABI3BP suppresses cardiac progenitor cell activation toward cardiac repair, but its suppression improves functional outcomes post-myocardial infarction.

\section{ABI3BP in Cardiovascular Disease}

In African Americans living in Tallahassee, Florida, USA, an $A B I 3 B P$ gene single nucleotide polymorphism was associated with patients having high blood pressure and experiencing unfair treatment (discrimination), implying that individuals possessing this single nucleotide polymorphism may be prone to enough distress during unfair treatment that it contributes to their high blood pressure (41). Of note, a single nucleotide polymorphism in the $A B I 3 B P$ gene was shown to be strongly associated with suicide attempts $(44,45)$. Thus, ABI3BP may contribute to neuropsychological distress alongside cardiovascular disease. Preeclampsia is a cardiovascular condition in pregnancy defined by pregnancy-induced hypertension and proteinuria. ABI3BP mRNA was upregulated in early-onset preeclampsia compared to late-onset preeclampsia and gestational age-matched controls (42). This study supports that ABI3BP is a potential contributor to severe cardiovascular disease.

In a survey of mouse models either susceptible to cigarette smoke-induced emphysema or not, they found that the genetic variation most significantly associated with susceptibility (i.e., comparing susceptible $\mathrm{A} / \mathrm{J}$ mice and in resistant $\mathrm{CBA} / \mathrm{J}$ mice) is in the $A B I 3 B P$ gene, with two mutations that are predicted to be deleterious. Susceptible A/J mice, lacking the key mutations, express $A B I 3 B P$ mRNA at 100-fold higher levels than the resistant CBA/J mice. Thus, a decrease in expression of $\mathrm{ABI} 3 \mathrm{BP}$ appears to be protective to cigarette smoke-induced emphysema. Perhaps, the authors speculate, this occurs by promoting regrowth and survival of the lung epithelium when $\mathrm{ABI} 3 \mathrm{BP}$ is absent (43). Recalling that ABI3BP is suspected to promote cellular senescence, it follows that its presence at higher levels in the lung inhibits lung epithelium regeneration.

\section{IMPLICATIONS OF ABI3BP IN CARDIOVASCULAR RESEARCH}

$\mathrm{ABI} 3 \mathrm{BP}$ is generally known as a component of the extracellular matrix. Studies of the isolated extracellular matrix from the heart and aorta show that it is a component of the extracellular matrix of the cardiovascular system specifically $(22,24,37)$. Furthermore, our study showed that ABI3BP levels were significantly reduced in failing human hearts with dilated cardiomyopathy (37). Pathological remodeling of the extracellular matrix of the heart and vasculature during the progression of cardiovascular disease plays an important role in disease pathology $(35,36)$. Thus, alteration of ABI3BP expression in the extracellular matrix during cardiovascular disease can be a cause and/or consequence of pathological remodeling. This possibility must be further explored to show whether $\mathrm{ABI} 3 \mathrm{BP}$ plays a role in pathological remodeling of the cardiovascular extracellular matrix, and whether inhibiting alterations in $\mathrm{ABI} 3 \mathrm{BP}$ expression can be a viable therapeutic target. Our laboratory is currently investigating the role of ABI3BP in cell-extracellular matrix adhesion in heart failure.

ABI3BP also affects cell cycle progression, promoting cellular senescence $(1,4,14)$. ABI3BP's presence in the heart and blood vessels may promote a normal homeostatic condition of low cell proliferation. However, reductions in ABI3BP in cardiovascular disease may increase proliferation of key cells involved repair, such as activated fibroblasts (myofibroblasts) and cardiac progenitor cells (40). However, ABI3BP reductions may also inhibit healing by blocking cardiac progenitor cell transdifferentiation toward cardiomyocytes (40), or its presence at high levels can inhibit healing due to attenuation of epithelial regeneration (43). $A B I 3 B P$ genetic mutations may also be responsible for early-onset preeclampsia (42). The potential role of $\mathrm{ABI} 3 \mathrm{BP}$ in senescence in cells of the cardiovascular system needs to be fully explored.

At the cutting edge of pre-clinical investigation and clinical trials for cardiac repair and regeneration are solid patches or injectable hydrogels comprised of isolated extracellular matrix. The extracellular matrix of the patches and hydrogels may be derived from mammalian tissues (including the heart), generated synthetically, or even a mixture of the two $(46,47)$. In many studies, the extracellular matrix is pre-seeded with a source of stem cells for implantation onto/into the heart. The expectation is that the patch/hydrogel will engraft with the native myocardial tissue, and the embedded stem cells would differentiate into cardiomyocytes, vascular endothelial cells, or other cardiac 
cells to promote myocardial repair and regeneration. Various sources of stem cells and extracellular matrix products have been tested. The ability of stem cells to engraft into the matrix material and differentiate into the desired cardiac cells is quite variable. It is possible that a uniform application of ABI3BP into the patch could improve stem cell adhesion, engraftment and cardiomyocyte differentiation, since current evidence supports that may ABI3BP play a role in cell-ECM adhesion and stem cell transdifferentiation $(4,24,37,40)$.

The possible roles for $\mathrm{ABI} 3 \mathrm{BP}$ in cardiovascular health maintenance and disease progression appear variable. It is difficult to ascertain whether it is a helpful or harmful protein in cardiovascular health and disease. However, the confusion in ABI3BP's role is likely due to the scarcity of studies published on this protein to date. These discrepancies might be resolved with an increase in active investigation into this intriguing new protein. With further investigation, ABI3BP may prove to be a novel therapeutic target for cardiovascular disease.

\section{REFERENCES}

1. Matsuda S, Iriyama C, Yokozaki S, Ichigotani Y, Shirafuji N, Yamaki $\mathrm{K}$, et al. Cloning and sequencing of a novel human gene that encodes a putative target protein of Nesh-SH3. J Hum Genet. (2001) 46:483-6. doi: $10.1007 /$ s100380170049

2. Terauchi K, Shimada J, Uekawa N, Yaoi T, Maruyama M, Fushiki S. Cancerassociated loss of TARSH gene expression in human primary lung cancer. $J$ Cancer Res Clin Oncol. (2006) 132:28-34. doi: 10.1007/s00432-005-0032-1

3. Uekawa N, Terauchi K, Nishikimi A, Shimada J, Maruyama M. Expression of TARSH gene in MEFs senescence and its potential implication in human lung cancer. Biochem Biophys Res Commun. (2005) 329:1031-8. doi: 10.1016/j.bbrc.2005.02.068

4. Hodgkinson CP, Naidoo V, Patti KG, Gomez JA, Schmeckpeper J, Zhang $\mathrm{Z}$, et al. Abi3bp is a multifunctional autocrine/paracrine factor that regulates mesenchymal stem cell biology. Stem Cells. (2013) 31:1669-82. doi: $10.1002 /$ stem.1416

5. Schulten H-J, Hussein D, Al-Adwani F, Karim S, Al-Maghrabi J, AlSharif M, et al. Microarray expression data identify DCC as a candidate gene for early meningioma progression. PLoS ONE. (2016) 11:e0153681. doi: 10.1371/journal.pone.0153681

6. Berghauser Pont LM, Spoor JK, Venkatesan S, Swagemakers S, Kloezeman JJ, Dirven $\mathrm{CM}$, et al. The $\mathrm{Bcl}-2$ inhibitor obatoclax overcomes resistance to histone deacetylase inhibitors SAHA and LBH589 as radiosensitizers in patient-derived glioblastoma stem-like cells. Genes Cancer. (2014) 5:445-59. doi: 10.18632/genesandcancer.42

7. Kafetzopoulou LE, Boocock DJ, Dhondalay GKR, Powe DG, Ball GR. Biomarker identification in breast cancer: beta-adrenergic receptor signaling and pathways to therapeutic response. Comput Struct Biotechnol. (2013) 6:e201303003. doi: 10.5936/csbj.201303003

8. Kim JC, Kim SY, Roh SA, Cho DH, Kim DD, Kim JH, et al. Gene expression profiling: canonical molecular changes and clinicopathological features in sporadic colorectal cancers. World J Gastroenterol. (2008) 14:666272. doi: 10.3748/wig. 14.6662

9. Britze A, Birkler RID, Gregersen N, Ovesen T, Palmfeldt J. Largescale proteomics differentiates cholesteatoma from surrounding tissues and identifies novel proteins related to the pathogenesis. PLoS ONE. (2014) 9:e104103. doi: 10.1371/journal.pone.0104103

10. Kristjansdottir B, Levan K, Partheen K, Carlsohn E, Sundfeldt K. Potential tumor biomarkers identified in ovarian cyst fluid by quantitative proteomic analysis, ITRAQ. Clin Proteomics. (2013) 10:4. doi: 10.1186/1559-0275-10-4

11. Nishikawa R, Goto Y, Sakamoto S, Chiyomaru T, Enokida H, Kojima S, et al. Tumor-suppressive microRNA-218 inhibits cancer cell migration and

\section{AUTHOR CONTRIBUTIONS}

DD, JD, and EM researched the articles cited in the review, and wrote and edited the manuscript in whole or in part, read and revised the final manuscript before submission, and approved the submitted version.

\section{FUNDING}

This work was supported by the American Heart Association (to DD, grant numbers 15BGIA22840012, 18AIREA33900010), the CTSC KL2 program (to DD, NIH grant number UL1TR001448), the NIH National Human Genome Research Institute FlyBase Postbaccalaureate Fellowship (to JD, grant number R25HG007630), and the University of New Mexico College of Pharmacy, and Cardiovascular and Metabolic Disease Signature Program (to DD).

invasion via targeting of LASP1 in prostate cancer. Cancer Sci. (2014) 105:80211. doi: $10.1111 /$ cas. 12441

12. Cerutti JM, Delcelo R, Amadei MJ, Nakabashi C, Maciel RM, Peterson B, et al. A preoperative diagnostic test that distinguishes benign from malignant thyroid carcinoma based on gene expression. J Clin Invest. (2004) 113:123442. doi: 10.1172/JCI19617

13. Guimarães GS, Latini FR, Camacho CP, Maciel RM, Dias-Neto E, Cerutti JM. Identification of candidates for tumor-specific alternative splicing in the thyroid. Genes Chromosomes Cancer. (2006) 45:540-53. doi: $10.1002 /$ gcc.20316

14. Latini FR, Hemerly JP, Oler G, Riggins GJ, Cerutti JM. Re-Expression of $\mathrm{ABI} 3$-binding protein suppresses thyroid tumor growth by promoting senescence and inhibiting invasion. Endocrine-Related Cancer. (2008) 15:78799. doi: 10.1677/ERC-08-0079

15. Salo S, Bitu C, Merkku K, Nyberg P, Bello IO, Vuoristo J, et al. Human bone marrow mesenchymal stem cells induce collagen production and tongue cancer invasion. PLoS ONE. (2013) 8:e77692. doi: 10.1371/journal.pone.0077692

16. Horpaopan S, Kirfel J, Peters S, Kloth M, Hüneburg R, Altmüller J, et al. Exome sequencing characterizes the somatic mutation spectrum of early serrated lesions in a patient with serrated polyposis syndrome (SPS). Hereditary Cancer Clin Pract. (2017) 15:22. doi: 10.1186/s13053-017-0082-9

17. Wakoh T, Uekawa N, Terauchi K, Sugimoto M, Ishigami A, Shimada J, et al. Implication of P53-dependent cellular senescence related gene, TARSH in tumor suppression. Biochem Biophys Res Commun. (2009) 380:807-12. doi: 10.1016/j.bbrc.2009.01.171

18. Wakoh T, Sugimoto M, Terauchi K, Shimada J, Maruyama M. A novel P53dependent apoptosis function of TARSH in tumor development. Nagoya J Med Sci. (2009) 71:109-14.

19. Ichigotani Y, Fujii K, Hamaguchi M, Matsuda S. In search of a function for the E3B1/Abi2/Argbp1/NESH family (review). Int J Mol Med. (2002) 9:591-5. doi: 10.3892/ijmm.9.6.591

20. Ichigotani Y, Yokozaki S, Fukuda Y, Hamaguchi M, Matsuda S. Forced expression of NESH suppresses motility and metastatic dissemination of malignant cells. Cancer Res. (2002) 62:2215-9.

21. Latini FR, Hemerly JP, Freitas BC, Oler G, Riggins GJ, Cerutti JM. $\mathrm{ABI} 3$ ectopic expression reduces in vitro and in vivo cell growth properties while inducing senescence. BMC Cancer. (2011) 11:11. doi: 10.1186/1471-2407-11-11

22. Didangelos A, Yin X, Mandal K, Baumert M, Jahangiri M, Mayr M. Proteomics characterization of extracellular space components in the human aorta. Mol Cell Proteomics. (2010) 9:2048-62. doi: 10.1074/mcp.M110. 001693 
23. Naba A, Pearce OMT, Del Rosario A, Ma D, Ding $H$, Rajeeve V, et al. Characterization of the extracellular matrix of normal and diseased tissues using proteomics. J Proteome Res. (2017) 16:3083-91. doi: 10.1021/acs.jproteome.7b00191

24. Barallobre-Barreiro J, Gupta SK, Zoccarato A, Kitazume-Taneike R, Fava $\mathrm{M}$, Yin X, et al. Glycoproteomics reveals decorin peptides with antimyostatin activity in human atrial fibrillation. Circulation. (2016) 134:817-32. doi: 10.1161/CIRCULATIONAHA.115.016423

25. ABI3BP. Target of Nesh-SH3 Precursor-Homo Sapiens (Human)_ABI3BP Gene \& Protein. (2003). Available online at: https://www.uniprot.org/uniprot/ Q7Z7G0 (Accessed October 23, 2018).

26. ABI3BP. ABI Family Member 3 Binding Protein [Homo Sapiens (Human)]Gene-NCBI. (2005). Available online at: https://www.ncbi.nlm.nih.gov/ gene/?term $=25890$ (Accessed October 23, 2018).

27. Piek A, de Boer RA, Silljé HH. The fibrosis-cell death axis in heart failure. Heart Fail Rev. (2016) 21:199-211. doi: 10.1007/s10741-016-9536-9

28. Bergmann O, Bhardwaj RD, Bernard S, Zdunek S, Barnabé-Heider F, Walsh $\mathrm{S}$, et al. Evidence for cardiomyocyte renewal in humans. Science. (2009) 324:98-102. doi: 10.1126/science. 1164680

29. Elson EL, Qian H, Fee JA, Wakatsuki T. A model for positive feedback control of the transformation of fibroblasts to myofibroblasts. Prog Biophys Mol Biol. (2018). doi: 10.1016/j.pbiomolbio.2018.08.004 [Epub ahead of print]

30. Frangogiannis NG. Cardiac fibrosis: cell biological mechanisms, molecular pathways and therapeutic opportunities. Mol Aspects Med. (2018) 65:70-99. doi: 10.1016/j.mam.2018.07.001

31. Takawale A, Sakamuri SS, Kassiri Z. Extracellular matrix communication and turnover in cardiac physiology and pathology. Comprehens Physiol. (2015) 5:687-719. doi: 10.1002/cphy. c140045

32. Valiente-Alandi I, Schafer AE, Blaxall BC. Extracellular matrix-mediated cellular communication in the heart. J Mol Cell Cardiol. (2016) 91:228-37. doi: 10.1016/j.yjmcc.2016.01.011

33. Bang C, Antoniades C, Antonopoulos AS, Eriksson U, Franssen C, Hamdani $\mathrm{N}$, et al. Intercellular communication lessons in heart failure. Eur J Heart Fail. (2015) 17:1091-103. doi: 10.1002/ejhf.399

34. Marchand M, Monnot C, Muller L, Germain S. Extracellular matrix scaffolding in angiogenesis and capillary homeostasis. Semin Cell Dev Biol. (2018). doi: 10.1016/j.semcdb.2018.08.007 [Epub ahead of print]

35. Imanaka-Yoshida K. Extracellular matrix remodeling in vascular development and disease. In: Nakanishi T, Markwald RR, Baldwin HS, Keller BB, Srivastava D, Yamagishi H, editors. Etiology and Morphogenesis of Congenital Heart Disease: From Gene Function and Cellular Interaction to Morphology. Tokyo: Springer (2016). Available online at: http://www.ncbi. nlm.nih.gov/books/NBK500279/

36. Li L, Zhao Q, Kong W. Extracellular matrix remodeling and cardiac fibrosis. Matrix Biol. (2018) 68-69, 490-506. doi: 10.1016/j.matbio.2018.01.013

37. DeAguero JL, McKown EN, Zhang L, Keirsey J, Fischer EG, Samedi VG, et al. Altered protein levels in the isolated extracellular matrix of failing human hearts with dilated cardiomyopathy. Cardiovasc Pathol. (2017) 26:12-20. doi: 10.1016/j.carpath.2016.10.001

38. Yin X, Bern M, Xing Q, Ho J, Viner R, Mayr M. Glycoproteomic analysis of the secretome of human endothelial cells. Mol Cell Proteomics. (2013) 12:956-78. doi: 10.1074/mcp.M112.024018

39. Scherer C, Pfisterer L, Wagner AH, Hödebeck M, Cattaruzza M, Hecker M, et al. Arterial wall stress controls NFAT5 activity in vascular smooth muscle cells. J Am Heart Assoc. (2014) 3:e000626. doi: 10.1161/JAHA.113.000626

40. Hodgkinson CP, Gomez JA, Payne AJ, Zhang L, Wang X, Dal-Pra S, et al. Abi3bp regulates cardiac progenitor cell proliferation and differentiation. Circ Res. (2014) 115:1007-16. doi: 10.1161/CIRCRESAHA.115.304216

41. Quinlan J, Pearson LN, Clukay CJ, Mitchell MM, Boston Q, Gravlee CC, et al. Genetic loci and novel discrimination measures associated with blood pressure variation in African Americans living in Tallahassee. PLoS ONE. (2016) 11:e0167700. doi: 10.1371/journal.pone.0167700

42. Nevalainen J, Skarp S, Savolainen ER, Ryynänen M, Järvenpää J. Intrauterine growth restriction and placental gene expression in severe preeclampsia, comparing early-onset and late-onset forms. J Perinatal Med. (2017) 45:86977. doi: 10.1515/jpm-2016-0406

43. Radder JE, Gregory AD, Leme AS, Cho MH, Chu Y, Kelly NJ, et al. Variable susceptibility to cigarette smoke-induced emphysema in 34 inbred strains of mice implicates abi3bp in emphysema susceptibility. Am J Respir Cell Mol Biol. (2017) 57:367-75. doi: 10.1165/rcmb.2016-0220OC

44. Perlis RH, Huang J, Purcell S, Fava M, Rush AJ, Sullivan PF, et al. Genomewide association study of suicide attempts in mood disorder patients. Am J Psychiatry. (2010) 167:1499-507. doi: 10.1176/appi.ajp.2010.10040541

45. Kimbrel NA, Garrett ME, Dennis MF, Clinical Center Workgroup, Hauser MA, Ashley-Koch AE, et al. A genome-wide association study of suicide attempts and suicidal ideation in U.S. Military Veterans. Psychiatry Res. (2018) 269:64-9. doi: 10.1016/j.psychres.2018.07.017

46. Bejleri D, Davis ME. Decellularized extracellular matrix materials for cardiac repair and regeneration. Adv Healthcare Mater. (2019) 2019:1801217. doi: 10.1002/adhm.201801217

47. Spang MT, Christman KL. Extracellular matrix hydrogel therapies: in vivo applications and development. Acta Biomater. (2018) 68:1-14. doi: 10.1016/j.actbio.2017.12.019

Conflict of Interest Statement: The authors declare that the research was conducted in the absence of any commercial or financial relationships that could be construed as a potential conflict of interest.

Copyright (c) 2019 Delfín, DeAguero and McKown. This is an open-access article distributed under the terms of the Creative Commons Attribution License (CC BY). The use, distribution or reproduction in other forums is permitted, provided the original author(s) and the copyright owner(s) are credited and that the original publication in this journal is cited, in accordance with accepted academic practice. No use, distribution or reproduction is permitted which does not comply with these terms. 